\title{
Problems of Controlling Marketing Activities: The Case of The Industrial Sector in The United Arab Emirates
}

\author{
HUSSEIN ABDULLA EL-OMARI \\ Associate Professor of Marketing \\ Dept. of Business Administration, \\ College of Business \& Economics \\ United Arab Emirates University \\ United Arab Emirates
}

( Received 01.09.1423H, and Accepted 25.05.1424H )

\begin{abstract}
As competition in the UAE stiffens, marketing becomes more and more important as it plays an important role in enhancing business competence and the strategic role of marketing in maximizing the benefits of scarce resources and in increasing productivity. The increasing interest in marketing emphasizes the importance of using creative marketing strategies. The aim of this study was to examine the problems of controlling marketing activities in the industrial sector of the United Arab Emirates. The sample of the study was drawn from the Emirate of Abu Dhabi and based on a quantitative approach. the study concluded that controlling marketing activities in the manufacturing sector of the UAE is weak and that many factors (e.g., lack of the required information, environmental changes, the time difference between performing marketing activities and their effects, difficulty in determining precise costs of marketing activities, difficulty in developing performance standards, general government intervention, lack of required technology, lack of qualified personnel, the production orientation of those manufacturers, and intangibility of marketing) have contributed to the creation of this situation.
\end{abstract}

\section{Introduction}

There are three main reasons for continuous interest in marketing. These are: (a) The role of marketing in enhancing business competence (b) the strategic role of marketing in maximizing the benefits of scarce resources, which comes as a result of producing what is required to satisfy consumer needs and wants (i.e., the Marketing concept) and (c) the strategic role of marketing in increasing productivity (e.g., Anderson and Vincze 2000, p. 50; Kotler and Armstrong 2001, p. 32). 
The managerial planning and operations of any business organization should be aimed at satisfying consumers' long-run needs and wants. Societal interests and the overall profit of these organizations should be achieved through consumers' satisfaction (e.g., Rayport and Sviokla 1994, p. 81; Storts 1990, p. 14; Wang and Petrison 1991, p. 16; Werner and Kumar 2000, p. 24).

Writers, researchers and businessmen see marketing as the focal point for the success of any system of business management. The managerial activities of any marketing-oriented firm should be aimed at making the marketing process more effective (e.g., Allen 1998, p. 13; Ambler 1998, pp. 24-25; Barner 1988, p. 17; Breen, Pecora and McCable 1997, pp. 38-41).

In the marketing process, a firm should start with identifying and analyzing its market(s). After this is done, the management of the firm has four elements to consider in its marketing strategy and these elements are: the product, the price, the place and the overall promotional part of the strategy. These four elements are comprised of marketing activities which the firm uses to achieve the most effective marketing mix, that is, the best possible outcome of these marketing activities. Through the use of marketing activities, especially in the areas of channel structure and promotion of the marketing mix, management should make an extensive use of the human factor. Moreover, in all stages of implementing the marketing program, management should exercise control over the marketing activities to achieve all of the above (e.g., Batra, et al., 1995, pp. 22-26; Chaker 1998, pp.1,9).

Although UAE firms, like most firms of other developing countries, do not fully adopt the marketing concept, they still practice many marketing activities (Kinsey 1988, pp. 20-63). Thus, the main aim of this study is to examine whether or not UAE manufacturing firms control these marketing activities and what are the main factors that create the problem when controlling these activities. In doing so, this study is trying to add to the marketing literature on the UAE which almost non-existent.

\section{Controlling marketing activities}

Controlling is an important function of the management process. It includes the "measuring of the actual performance, comparing performance to the standards established for a plan, and taking corrective action when necessary"(e.g., Hawthorne 1998, p. 52-53; Paley 1994, pp. 43-44; Piercy and Morgan 1994, pp. 167-178).

Marketing managers realize that marketing strategies seldom work out exactly as planned and, therefore, it is important to control marketing activities to take corrective actions if deviations from the plan exist.

By getting the appropriate information, firms can improve the effectiveness of their marketing strategies. To do this, firms need to have good controlling systems and this, of course, requires the use of the right information as a guide to action. Information could be obtained from secondary sources (e.g., magazines and newspapers) and from primary sources (e.g. by conducting a research). Primary sources are used more and more frequently in local business environments as well as in global ones which are becoming more competitive and complicated. Even with careful research, there are some limitations on how dependable such information and projections can be. However, if the knowledge obtained has some degree of relevance and accuracy, it will facilitate the control function and improve the degree of marketing success (e.g., Cressman 1994, 
pp. 41-63; Deighot 1996, p. 145; Donath 1992, p. 21; Farrel 1993, pp. 148-153; Fitzerald 1994, pp. 8 and 10; Graham 1998, 32 and 62).

As mentioned earlier the marketing control process includes the establishment of performance standards, evaluating actual performance against these established standard :. and then narrowing the differences between planned and actual performance. Ihis is necessary if the marketing manager wishes to integrate all the marketing activities into a unified marketing plan. Any marketing manager who sees and feels the impact of this basic idea discovers that marketing is a process that is constantly evolving and never static. Marketing managers must control and continue to control their firms' marketing activities in order to build a good marketing program (e.g., Ganesan 1994, p. 1; Hardy 1993, p. 79). This is important for attracting buyers in any market and maximizing profit through customers' satisfaction.

Comparing actual performance with established standards requires marketing managers to be fully aware of all marketing activities within their companies and have enough information regarding the marketing activities of external organizations in the market. Pride and Ferrell (1989) stated:

"Information is required about the activities of marketing personnel at the operations level and at various marketing management levels. Most businesses obtain marketing assistance from one or more external individuals or organizations, such as advertising agencies, middlemen, marketing research firms, and consultants. To maximize benefits from external sources, a firm's marketing control process must monitor their activities. Although it may be difficult to obtain the necessary information, it is impossible to measure actual performance without it'(p. 683)

Many techniques of evaluating and controlling marketing activities are usually available to marketing mangers. Sales analysis and marketing cost are the most widely used. In the sales analysis technique, segments where sales performance problems exist are iden'ified. For example, if a company's sales are not growing and has a complex line of products, it will be difficult for the company to determine which product has a poor performance without sales analysis. By organizing the sales of a particular product, for instance, management can obtain immediate insights as to whether the product's performance is as planned or not. However, this method does not indicate what corrective action(s) should be taken if the product's performance is below the expected level. Moreover, although this technique may help in evaluating the marketing strategy, it does not tell whether the overall strategy is profitable or not (e.g., Rasmusson 1998, p. 19; Shank and Govindarajan 1989, pp. 101-110)

In marketing cost analysis technique, the marketing costs are broken down and classified into categories. For example, sales costs are classified by salespersons, territories, customers or products. This classification is important to determine which part of the overall marketing costs are spent on performing a particular marketing activity and so on. By doing so, marketing managers can identify where performance is not up to the planned standards and, hence, a corrective action may be taken. For instance, by examining the different classifications of sales costs, marketing managers can determine if some of them are unnecessarily high and, if so, corrective action may be taken as a result. 


\section{Problems in controlling marketing activities}

The process of managing marketing primarily includes, planning a program, executing it, and evaluating its results against determined standards. The changing business environments and the dynamic nature of the socioeconomic systems in these environments have made planning mandatory in virtually any marketing organization. In spite of all the careful planning, marketing managers still run into many problems when attempting to control marketing activities (e.g., Anderson and Vincze 2000, pp. 65-79; Miles and Snow 1992, p. 67; Narus and Pinchak 1984, pp. 142-145; Stanton 1981, 70-103).

The unavailability of the required information is one big problem that faces marketing managers in controlling marketing activities. We all agree that information is important for the future and the survival of any business organization (e.g., Graham 1998 , p. 62 ; Hardy 1993, pp. 79-82). Therefore, marketing managers must anticipate any future changes, anticipate the direction and intensity of these changes and, hence, take any corrective to action re-arm their marketing programs to encounter the new changes (e.g., Hurley and Hult 1998, p. 44; Leyland, et al., 1994, pp. 169-174). In spite of the preferability of applying the concept of flexibility to the control of marketing activities to allow for environmental changes, the continuity, intensity, and unpredictability of these changes may hamper effective control (Pride and Ferrell, 1989, p. 683; Stuck 1995 , p.2). To effectively manage their marketing activities, business organizations need marketing information systems. The use of marketing information systems should permeate every phase of the marketing program, which is the case in most companies in the West and the US as opposed to those of developing countries (e.g., Kinsey 1988, 95-103).

Marketing activities require time to achieve there intended effect on the target market. For example, advertising needs some time to persuade people to adopt a product. Therefore, the time difference between performing these marketing activities and their intended effects may limit marketing managers' ability to measure the effectiveness of these activities (e.g., Rust and Oliver 1994, p. 75; Schultz 1997, p. 10).

Unrealistic performance standards cause different problems in the control of marketing activities. For example, when new products or services are just introduced to a market, managers may overestimate the speed with which the market will respond and, therefore, unrealistic sales goals may be determined (e.g., Graham 1998, p. 32; Rasmusson 1998, p. 19).

The unanticipated environmental changes may also hamper the control of marketing activities. For example, profit standards determined in a business plan may not be reached if the supplier suddenly decides to increase prices (e.g., Cressman 1994, pp. 4163; Miles and Snow 1992, p. 67; Shank and Govindarajan 1989, p. 106).

The ineffective implementation of marketing activities will hamper the control of these activities. This situation may occur for many reasons. A conflict in performing responsibilities may be given as an example. However, ineffective implementation of marketing activities in developing countries may come as a result of the way marketing is viewed in these countries. Marketing is usually viewed as an art rather than as a science and also is perceived as no more than the selling of products and services. In addition to that, the production orientation of business organizations in these countries and the idea 
that marketing suits only western economies will hamper the implementation of marketing activities (e.g., Kaynak 1982, p. 48-103; Kinsey 1988, 95-103).

Finally, the overlap of business activities makes it difficult for marketing managers to know the exact cost of marketing activities. Without knowing the exact cost of marketing, it will be difficult to decide whether the effects of marketing activities are worth their expense (Pride and Ferrell, 1989, p. 683)

\section{Why manufacturers}

Any form of research has limitations and restricting the scope of this study to the industrial sector is a typical example of research of this type. Covering all economic sectors would require a study or studies of $\mathrm{PhD}$ nature. Therefore, the application of the current study is narrowed to the industrial sector, which was selected for the following reasons.

a) Marketing studies in this sector are almost non existent and hence, this study attempts to provide insight into what is happening here.

b) UAE citizens usually view locally-made products as inferior to their imported ones. Thus, UAE manufacturers need to do their utmost to change this attitude if they wish to complete effectively. This image can be changed through the implementation of an effective marketing program and, hence, controlling would become an important tool in maintaining its' effectiveness.

\section{Purpose of the study}

The overall purpose of this study is to examine whether or not UAE manufacturers control their marketing activities, and if they do so, what are the main factors that create problems when controlling these marketing activities

\section{Main hypotheses of the study}

The literature review and the researchers' experience in the UAE market have led to the development of the following main hypotheses.

H1: Manufacturers' concern regarding the control of their marketing activities is related to the lack of the necessary information

H2: Manufacturers' concern regarding the control of their marketing activities is related to the lack of required technology

H3: Manufacturers' concern regarding the control of their marketing activities is related to government interventions in some of these activities (e.g. interventions in price)

\section{Methodology:}

\section{The Sample Frame and Data Collection:}

A list of all manufacturers in the Emirate of Abu Dhabi was obtained from the Annual Report of Abu Dhabi Chamber of Commerce and Industry (2000), p. 57. According to this Report (the latest), the number of factories in each of the industries that existed in the Emirate of Abu Dhabi, at that time, are as follows: 


\begin{tabular}{|c|c|}
\hline Industrial Sector & Number of Factories \\
\hline Oil Refining & 5 \\
\hline Vehicles \& Trailers & 5 \\
\hline \multicolumn{2}{|l|}{ Furniture \& Other } \\
\hline Manufacturing Industries & 16 \\
\hline Publications \& Printing & 7 \\
\hline Chemicals \& Associated Products & 22 \\
\hline Non-Metal Mineral Products & 45 \\
\hline Basic Metals & 4 \\
\hline Metal Products & 41 \\
\hline Machinery \& Equipment & 5 \\
\hline Electrical Appliances \& Accessories & 6 \\
\hline Other Transport Equipment & 3 \\
\hline Foodstuff \& Beverages & 18 \\
\hline Garments & 9 \\
\hline Paper \& Paper Products & 8 \\
\hline Rubber \& Plastic Products & 21 \\
\hline Total & 215 \\
\hline
\end{tabular}

After careful screening to determine who is still in business and who is not and their exact addresses, all 145 factories of five major industries (i.e., Manufacturing Industries, Chemical \& Associated products, Non-Metal Mineral Products, Metals Products and Rubber \& Plastic Products) were selected as the population for the study. The Emirate of Abu Dhabi was selected as the field of the study as it has the most powerful economy of all of the seven Emirates and is the governmental capital of the United Arab Emirates. In addition, Its area is about 67,000 kilometers and it is the largest of the Emirates in the federation of the United Arab Emirates.

Phone calls were made to the selected manufacturers to explain the nature and the purpose of the study. After that, 145 questionnaires (with dichotomous type questions, i.e., Yes and No) were mailed to the sales/marketing managers of those manufacturers. Of the 145 questionnaires sent, 102 usable questionnaires were returned. Therefore, the overall response rate was $70.3 \%$.

\section{Data analyses}

To investigate whether or not UAE manufacturers control or try to control their marketing activities, respondents were asked question No. 1 of the questionnaire (see appendix). Table (1) shows the results

Table (1)

Controlling marketing activities by UAE manufacturers

\begin{tabular}{|l|ll|}
\hline Response & $\mathrm{N}$ & $\%$ \\
\hline Yes & 70 & 69.0 \\
No & 32 & 31.0 \\
\hline
\end{tabular}

102 Cases

0 Missing value

Table (1) shows that the majority of UAE manufacturers control or try to control their marketing activities, which means that there is a general understanding amongst those manufacturers regarding the importance of controlling the marketing activities. To examine if those manufacturers have any problems regarding the control of their marketing activities, respondents were asked question No 2. Table (2) reveals the results. 
Table (2)

Problems regarding manufacturers' control of their marketing activities

\begin{tabular}{|l|lc|}
\hline Response & $\mathrm{N}$ & $\%$ \\
\hline Yes & 91 & 89.2 \\
No & 11 & 10.8 \\
\hline
\end{tabular}

102 Cases

\section{Missing value}

It is clear from table (2) that those manufacturers have real problems when it comes to controlling their marketing activities, as $\mathbf{8 9 . 2 \%}$ of respondents have indicated so. To examine the factors that create these problems, respondents were given question No. 3. Table (3) reveals the results.

Table (3)

Factors that are creating the problems when controlling marketing activities

\begin{tabular}{|c|c|c|c|c|}
\hline \multirow[b]{2}{*}{ Problem } & \multicolumn{2}{|c|}{ Yes } & \multicolumn{2}{|c|}{ No } \\
\hline & $\mathrm{n}$ & $\%$ & $\mathrm{n}$ & $\%$ \\
\hline Q3a-Unavailability of the necessary information. & 81 & 79.4 & 21 & 20.6 \\
\hline $\begin{array}{l}\text { Q3b-Frequency, intensity, and unpredictability of } \\
\text { environmental changes. }\end{array}$ & 75 & 73.5 & 27 & 26.5 \\
\hline $\begin{array}{l}\text { Q3c- Managers' inability to measure activities' } \\
\text { effectiveness as a result of the time difference between } \\
\text { performing marketing activities and their effects. }\end{array}$ & 69 & 67.6 & 33 & 32.4 \\
\hline $\begin{array}{l}\text { Q3d-The difficulty in determining the precise costs } \\
\text { of marketing activities. }\end{array}$ & 67 & 65.7 & 35 & 34.3 \\
\hline $\begin{array}{l}\text { Q3e-The difficulty in developing performance } \\
\text { standards. }\end{array}$ & 71 & 69.6 & 31 & 30.4 \\
\hline $\begin{array}{l}\text { Q3f-General government interventions in some of } \\
\text { these activities (e.g.price intervention). }\end{array}$ & 77 & 75.5 & 25 & 24.5 \\
\hline $\begin{array}{l}\text { Q3g-Lack of the required technology for controlling } \\
\text { marketing activities (e.g., technology required for } \\
\text { establishing and managing marketing information } \\
\text { systems). }\end{array}$ & 79 & 77.5 & 23 & 22.5 \\
\hline Q3h-Lack of qualified personnel for doing the job. & 63 & 61.8 & 39 & 38.2 \\
\hline $\begin{array}{l}\text { Q3i-The production orientation rather than the } \\
\text { marketing orientation has distracted the attention of } \\
\text { all concerned personnel from these marketing } \\
\text { activities and the way they should be controlled. }\end{array}$ & 61 & 59.8 & 41 & 40.2 \\
\hline $\begin{array}{l}\text { Q3j-Intangibility of marketing has also distracted } \\
\text { the attention of all concerned personnel from these } \\
\text { marketing activities and the way things should be } \\
\text { controlled }\end{array}$ & 59 & 57.8 & 43 & 42.2 \\
\hline Q3k-Others, please specify.. & & & & \\
\hline
\end{tabular}

Table (3) shows that many factors contribute in creating the problems that UAE manufacturers face when controlling their marketing activities. To further examine the link between these factors and the overall problems of controlling these activities, and to test the study hypotheses, a cross-tabulation technique using Chi-square test of significance was employed. Table (4) indicates the results. 
Table (4)

The overall problems of controlling marketing activities by the causal factors

\begin{tabular}{|l|lll|}
\hline \multicolumn{1}{|c|}{ Factor } & Chi-square & df & $\begin{array}{c}\text { level of } \\
\text { significance }\end{array}$ \\
\hline - Unavailability of the necessary information. & 6.976 & 1 & $* *$ \\
\hline - Environmental changes. & 6.785 & 1 & $* *$ \\
\hline $\begin{array}{l}\text { - The time difference between performing } \\
\text { marketing activities and their effects. }\end{array}$ & 6.681 & 1 & $* *$ \\
\hline $\begin{array}{l}\text { - Difficulty in determining precise costs of } \\
\text { marketing activities. }\end{array}$ & 6.657 & 1 & $* *$ \\
\hline - Difficulty in developing performance standards. & 6.734 & 1 & $* *$ \\
\hline - General government interventions. & 6.843 & 1 & $* *$ \\
\hline - Lack of required technology. & 6.865 & 1 & $* *$ \\
\hline - Lack of qualified personnel & 5.312 & 1 & $*$ \\
\hline - The production orientation of those manufacturers. & 5.105 & 1 & $*$ \\
\hline - Intangibility of marketing. & 4.837 & 1 & $*$ \\
\hline
\end{tabular}

102 Cases

0 missing value

** = Significant relationship at the 0.01 level

* = Significant relationship at the 0.05 level

Table (4) shows that all the factors included have significant relationships with the overall problems of controlling the marketing activities of UAE manufacturers, at the 0.01 and 0.05 levels. The study hypotheses (i.e., H1, H2 and H3) were, therefore, accepted at the 0.01 level of significance.

\section{Conclusions and recommendations}

Although most, if not all, business organizations in the UAE (as is the case in many developing countries) are production oriented, they do perform many marketing activities. To be effective, these activities need to be controlled and to be properly controlled, they need to be successfully organized and implemented. The successful implementation of these activities depends heavily on their planning and, therefore, this shows the relationship between these four management functions and emphasizes the importance of the marketing management process to business organizations.

Implementing a marketing strategy means how a particular marketing strategy is actually executed. The execution of a marketing strategy must be done through the daily functions of marketing managers, sales and customer service personnel, distributors, and in some situations, by non-marketing personnel. The success of any marketing strategy will depend heavily on the way the strategy is implemented. Effectiveness has the "Veto Power" which determines whether the implementation of a marketing strategy is successful and, therefore, controlling the activities of any marketing strategy is an important element, which helps in identifying any unsatisfactory levels of performance.

Because of continuous environmental changes, strategies are never perfect and, hence, marketing control is necessary. Managers must be always be ready to modify the marketing strategy or the implementation of the strategy if unsatisfactory performance is experienced or anticipated.

The findings of this study have indicated that controlling the marketing activities in the manufacturing sector of the UAE is weak and that many factors have contributed to the creation of this situation. 
These marketing activities are costly, in terms of time and money and, hence, manufacturers need to take this seriously as this situation means an increase in the firm's cost of products. This is important for manufacturers if they wish to compete effectively as most if not all, UAE citizens frequently regard locally-made products as inferior in their imported rivals. They also believe that imported products are superior to local ones and, hence, successful and effective implementation of marketing activities will result in a "cost-reduction" strategy; which, in turn, may give the required competitive edge.

A more positive move by those manufacturers towards marketing orientation and the increasing interest in technology amongst UAE citizens will reduce the overall problems of controlling manufacturers' marketing activities. However, those manufacturers need to have their own marketing information systems. Those systems are the major tools that are usually used by managements to aid in problem solving and decision-making. The use of those tools should permeate every phase of a company's marketing program. After all, "to manage a business well is to manage it's future, and to manage the future is to manage information" (Harper 1961, p.1)

\section{References}

Abu Dhabi Chamber of Commerce and Industry (2000) Annual Report, UAE, p. 57.

Allen, Robin (1998) "The NRN 50-The Franchisees: Foodservice's Theory of Evaluation: Survival of the Fittest", Nation's Restaurant News, January 1998, pp. 12-15ff.

Amb!cr, Tim (1998) "Why Is Marketing Not Measuring Up?, Marketing, September 24, pp. 24-25.

Anderson, Carol and Vincze, Julian (2000) Strategic Marketing Mariagement: Meeting The Global Marketing Management. $1^{\text {st }}$ ed., Houghton Mifflin, Boston, USA.

Barner, R. (1988) "The New Millennium Workplace: Seven Changes That Will Challenge Managers-and Workers", Futurist, 30(20), pp. 14-18.

Batra, Rajeev; Lehman, Donald; Burke, Joanne and Pae, Jae (1995) "When Does Advertising Have an Impact? A Study of Tracking Data", Journal of Advertising Research, 35(10), S ptember-October, pp. 19-29.

Breen, Ken; Pecora, Jerry and McCable, Tom (1997) "A New Dimension: Integrated Management Systems", Quality Digest, August, pp. 36-41.

Chaker, Anne (1998) "Makeup Brands Take Note as Day Spas Sell Cosmetics", Wall Street Journal, July 8 , pp. 1,9 .

Cressman, George (1994) "Choosing The Right Metric", Drive Marketing Excellence, November, Institute For International research, New York., pp. 41-63.

Deighot, John (1996) "The Future of Interactive Marketing", Harvard Business Review, November-December, p. 154

Donath, Bob (1992) "Solving The Manufacturing vs. Marketing Contradiction", Marketing News, 26(24), November, p. 21.

Farrel, Christopher (1993) "Stuck! How Companies Cope When They Can't Raise Prices", Business Week, November 15, pp. 146-155.

Fitzerald, Mark (1994) "Decentralizing Control of Purchasing", Editor and Publisher, June 18, pp. 8 \& 10.

Ganesan, Shankar (1994) "Determinants of Long-Term Orientation in Buyer-Seller Relationships", Journal of Marketing, 58 (April), pp. 1-19.

Graham, John (1998) "Ways to Evaliuate Marketing Program", Nation's Restaurant News, March 23, pp. 32 and 62.

Hardy, Kenneth (1993) "Tough New Marketing Realities", Business Quarterly, 57(3), Spring, pp. 77-82.

Harper, M. (1961) "New Profession To Aid Management", Journal of Marketing, January, p.1. 
Hawthorne, Tim (1998) "When and Why to Consider Infomercials", Target Marketing, February, pp. 52-53.

Hurley, Robert and Hult, Tomas (1998) "Innovation, Marketing Orientation, and Organizational Learning: An Integration and Empirical Examination”, Journal of Marketing, July, pp. 42-54.

Kaynak, E. (1982) Marketing In The Third World, $1^{\text {st }}$ ed., New York, USA.

Kinsey, J. (1988) Marketing In Developing Countries, MacMillan Education Ltd., Printed in Hong Kong. pp. 20-103.

Kotler, Philip and Armstrong, Gary (2001) Principles of Marketing, ${ }^{\text {th }}$ ed., Prentice-Hall, New Jersey, USA. pp. 665-701.

Leyland Pitt, Pierre Berthoin, and Berthon Jean-Paul (1999) "Changing Channels: The Impact of Ti, Internet on Distribution Strategy", Business Horizon, March-April, pp. 19-28.

Miles, R. E. and Snow, C. C. (1992) "Causes of Failure in Network Organizations", California Management Review, 241(5), pp. 53-72.

Narus J, Reddy M and Pinchak G (1984) "Key Problems Facing Industrial Distributors", Industrial Marketing Management, 13, pp. 139-147.

Paley, Norton (1994) "Cut Out For Success", Sales and Marketing Management, 147, April, pp. 43-44.

Piercy, Nigel and Morgan, Neil (1994) "The Marketing Planning Process: Behavioral Problems Compared to Analytical Techniques in Explaining Marketing Plan Credibility", Journal of Business Research, 29, pp. 167-178.

Pride, O. and Ferrell O. (1989) Marketing : Concepts and Strategies, $5^{\text {th }}$ ed., Houghton Mifflin, USA, p. 683.

Rasmusson, Erika (1998) "Tracking Down Sales", Sales and Marketing Management, June, p. 19.

Rayport, Jeffrey and Sviokla, John (1994) "Managing in The Marketplace", Harvard Business Review, November-December, pp. 75-85.

Rust, Ronald and Oliver, Richard (1994) "Notes and Comments: The Death of Advertising", Journal of Advertising, December, pp. 71-77.

Schultz, Don (1997) “Check Out Your Level of Integration", Marketing News, August 18, p.10.

Shank, John and Govindarajan, Vijay (1989) Strategic Cost Analysis, Burr Ridge, IL: Irwin, pp. 99-112.

Stanton, W. (1981) Fundamentals of Marketing, $6^{\text {th }}$ ed., McGraw-Hill Company, USA, pp. 72-103.

Storts, William (1990) Using Technology to Shape S\& L Marketing Strategies, Bottomline (BTL), 7(3), March, pp. 11-16.

Stuck, B. (1995) "Collaboration: Working Together Apart", Business Communication Review (Networking Supplement), February, pp. 9-11ff.

Wang, Paul and Petrison, Lisa (1991) "Integrated Marketing Communications and its Potential E fects on Media Planning", Journal of Media Planning, 6, No. 2, pp. 11-18.

Werner J. Reinarz and kumar V. (2000) "On The Profitability of Long-Life Customers In a Noncontractual Setting: An Empirical Investigation and Implications For Marketing", Journal of Marketing, 64, October, PP. 17-35. 


\section{Questionnaire:}

\section{Appendix}

Q1-As a marketing/sales manager, does your company control or try to control its marketing activities (e.g., advertising, pricing, ...., etc.) in order to take corrective actions to reach determined performance standards?

$$
\text { Yes........ No........ }
$$

Q2-Does your company have any problems regarding the control of its marketing activities?

$$
\text { Yes........ No........ }
$$

Q3-Do you consider the following as factors in creating the controlling problems of any marketing activities?

a) Necessary information is either unavailable or very hard to find.

$$
\text { Yes........ No........ }
$$

b) The frequency, intensity, and unpredictability of environmental changes hamper your ability to have effective control.

$$
\text { Yes. }
$$$$
\text { No......... }
$$

c) The time difference between performance of marketing activities and their effects limits managers' ability to measure activities effectiveness.

Yes.

No.

d) The precise costs of marketing activities cannot be determined.

$$
\text { Yes. }
$$

No

e) It may be difficult to develop performance standards.

$$
\text { Yes........ No........ }
$$

f) Government interventions in some of these activities (e.g., prices and distribution).

$$
\text { Yes......... No........ }
$$

g). Lack of technology required for establishing and managing marketing information systems?

$$
\text { Yes........ No........ }
$$

h) Lack of qualified personnel for doing the job.

$$
\text { Yes........ No........ }
$$

i) The production orientation rather than the marketing orientation of your company has distracted the attention of all concerned personnel from these marketing activities and the way they should be controlled.

$$
\text { Yes........ No........ }
$$

j) Intangibility of marketing has also distracted the attention of all personnel from these marketing activities and the way they should be controlled.

Yes........ No........

k) Others please, specify 


\section{مشاكل السيطرة على الأنشطة التسويقية: حالة تطلاع الصناعة في دولة الإمارات العربية المتحدة}

$$
\begin{aligned}
& \text { حسين عبدالله العمري }
\end{aligned}
$$

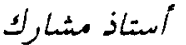

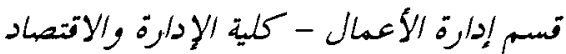

$$
\begin{aligned}
& \text { جامعة الإمارات العربية المتحلة - الإمارات العربية المتحدة }
\end{aligned}
$$

المستخلص : إن ازديـاد حهـم المنافسـة في دوله الإمـارات العربية المثتحدة أدى إلى زيـادة

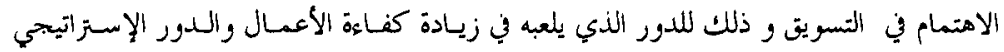

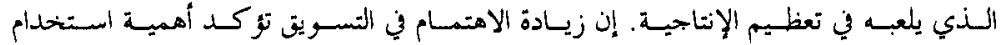

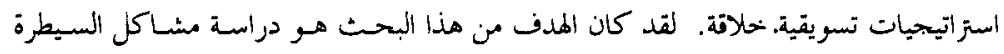

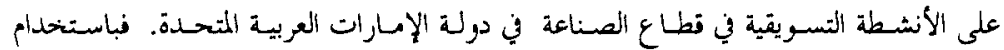

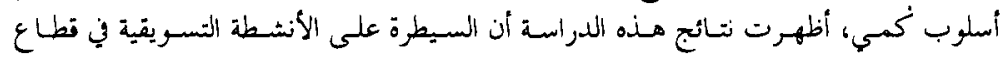

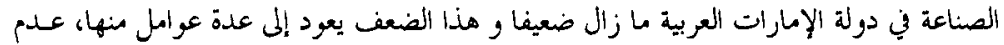

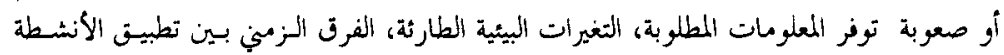

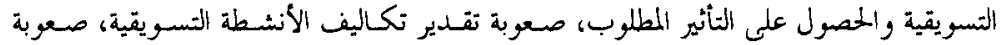

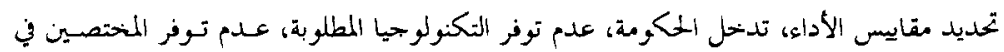

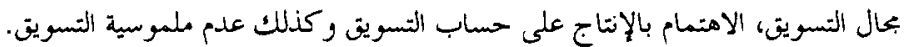

